\title{
Üniversite Öğrencilerinin Toplumsal Cinsiyet Rolleri Ve Çatışma Çözme Stillerinin İncelenmesi
}

\author{
Examining the Gender Role and Conflict Resolution Styles of \\ University Students
}

\author{
Gülşen BÜYÜKŞAHIN ÇEVIK**
}

Öz: Bu araştırmanın amacı Adıyaman Üniversitesi'ndeki öğrencilerin toplumsal cinsiyet rolleri ve çatışma çözme stillerini incelemektir. Araştırmada Adıyaman Üniversitesine 2015-2016 eğitim-öğretim yılında devam eden 209'i erkek (\% 45,6) ve 249’u (\% 54,4) kadınlardan olmak üzere toplam 458 kişi ( $\bar{X}$ yaş=22,39, $\mathrm{Sd}=1,76$, ranj= 19-37) çalışma grubunu oluşturmuştur. Araştırmada veri toplamak amaciyla araştırmacının geliştirdiği “Kişisel Bilgi Formu”, Zeyneloğlu ve Terzioğlu’nun (2011) geliştirdiği Toplumsal Cinsiyet Rolleri Ölçeği ve Johnson ve Johnson (2008) tarafindan geliştirilen Türkçe'ye Uyarlaması Karadağ ve Tosun (2014) tarafından yapılan Çatışma Eylem Stilleri Ölçeği kullanılmıştır. Araştırmanın verileri betimsel istatistikler, Pearson Momentler Çarpımı Korelasyonu, çok değişkenli varyans analizi (Tek Yönlü MANOVA) ve post-hoc çoklu karşılaştırma testlerinden Tukey HSD testi kullanılarak analiz edilmiştir. Araştırma bulgularına göre, eşitlikçi cinsiyet rollerinin, kadınsı cinsiyet rollerinin, erkeksi cinsiyet rollerinin, evlilikte cinsiyet rollerini, geleneksel cinsiyet ve toplumsal cinsiyet rolllerinin erkeklerde ortalamasının kadınlara oranla anlamlı olarak daha yüksek olduğu ortaya çıkmıştır. Ayrıca cinsiyete göre çatışma stillerinin farklılaşmadı̆̆ı ortaya çıkmıştır.

Anahtar Kelimeler: Toplumsal cinsiyet rolü, çatışma eylem stili, üniversite öğrencileri

\begin{abstract}
The current study aims to examine gender roles and conflict resolution in university students in Adiyaman University in Turkey. Research participants consisted of totally 458 individuals ( $\bar{X}$ age $=22.39$, $S D=1.76$, range=19-37) including $209(45.6 \%)$ males and $249(54.4 \%)$ females attending Adiyaman University in 2015-2016 academic years in Turkey. The data were collected through a personal information form designed by the researcher, Gender Roles Attıtude Scale developed by Zeyneloğlu (2008) and Conflict Activity Styles Inventory developed by Johnson ve Johnson (2008) and adapted by Karadağ ve Tosun (2014). In order to analyze the Pearson Correlation Coefficient, One way MANOVA and Tukey HSD analysis method were employed. According to findings, negatively significant correlation was found between burnout and resilience. According to gender, it is not observed a significant difference for the resilience and burnout. The findings of the present study were discussed in the light of the related literature. The means of egalitarian gender roles, feminine gender roles and masculine gender roles, gender roles in marriage, traditional gender roles, and social gender roles in males were found to be significantly higher than those in females.

Keywords: Gender role, conflict activity style, university students
\end{abstract}

\section{Giriş}

Toplumsal cinsiyet kadın ve erkeğe özgü davranışların bir toplumda istenen ölçütlere uygun davranılması olarak betimlenebilir. Toplumsal cinsiyet rolü (gender role), bir toplumun kültürünün kadın ve erkekten beklentilerini ifade eder (Helgeson, 2012). Cinsiyet, kadın ve erkeğin sosyal ve kültürel olarak tanımlanmasını, toplumun kadın ve erkeği ayırt etmesini ve toplumsal rolleri içermektedir. Cinsiyet rollleri kadın ve erkeğin toplumsal gerçeklerini anlamanın bir aracı olduğu belirtilmiştir (Bhasin, 2003). Sosyal Öğrenme kuramcılarına göre toplumsal cinsiyet ödül ve ceza yöntemi kullanılarak kazandırılmaktadır. Toplum tarafından istenen davranışlar onaylanır, toplum tarafından istenmeyen davranışlar ise cezalandırılır (Dusek, 1987). Biyolojik ölçütlere göre bir cinsiyet kategorisinde olmanın ötesinde, insanlar duygu, biliş

\footnotetext{
*Yrd. Doç. Dr., Adıyaman Üniversitesi, Eğitim Fakültesi, Adıyaman, e-posta: gbcevik@ adiyaman.edu.tr
} 
ve davranışların, kendi cinsiyet kategorileri için toplumun dayatma ve beklentileriyle uyuşacak biçimde nasıl yönetileceği gibi birçok karmaşık eylemi de öğrenirler. Bu etkinliklerin tümünün toplamına "toplumsal cinsiyet" adı verilmektedir (Hendrick, 2009). Bem (1993) her kültür ve toplumda kadın ve erkeğe ait kişilik özelliklerinin belirlendiğini vurgulamıştır. Buna göre kadın ve erkeğin bir toplumdaki yeri ve yapacağı işler açısından farklılaştığını belirtmektedir. Böylece çocukluktan itibaren birey kadın ve erkeğe ait davranış, görev ve sorumlulukları öğrenmektedir. Aynı zamanda bir toplumun kadın ve erkekten beklentilerine göre bilişsel şemalar geliştirdiğini öne sürmüştür. Aynı zamanda Bem (1974) kadınsı ve erkeksi özelliklerin bireylerde aynı zamanda bulunabileceğini belirterek androjen terimini ortaya koymuştur. Bem insanların, kadınsı özellikleri içeren örüntülere göre kadınsı (feminen) rol, erkeksi özellikleri içeren örüntülere göre erkeksi (maskülen) rol, her iki cinsiyetin özelliklerini içeren örüntülere androjen rol ve belirgin bir rol göstermeyen örüntülere belirsiz (undifferentiated) olmak üzere dört cinsiyet rolünden birine sahip olabileceğini ifade etmiştir. Giddens'e (1996) göre, "sex" kelimesi kadınlar ve erkekler arasındaki biyolojik ve anatomik farklılıkları içermekteyken, cinsel davranışlardan farklı olarak ele alındığını belirtmektedir. "Gender" kelimesi ise, kadın ve erkek arasındaki ruhsal, sosyal ve kültürel farklılıkları ortaya çıkarmak için kullanıldığı belirtilmektedir. Dolayısıyla kadınlarla erkekler arasındaki farkların birçoğunun biyolojik olmadığını belirtmektedir. $\mathrm{Bu}$ nedenle kadının yaptığı pek çok işi erkeğin de yapabilecek güç, yetenek, zekâ, fiziksel ve zihinsel güce sahip olmasına rağmen toplumsal kalıp yargılarıyla büyütülerek yapılamazmış imajı yaratıldığı belirtilmektedir (Dökmen, 2004).

Geleneksel cinsiyet rolü toplum içinde yaygın bir şekilde erkeksi (masculine) ya da kadınsı (feminine) olarak bilinen davranış, tutum, değer, düşünme biçimleri, yürüme, giyinme ve bireyin bedenini süslemeyi kapsayan özellikler toplamı olarak tanımlanmıştır (Gander ve Gardiner, 1995). Androjen cinsiyet rolü bireylerin hem kadınsı hem de erkeksi özellikleri bir arada ve farklı derecelerde sergilediği cinsiyet rolü olarak tanımlanmıştır (Mayer ve Sutton, 1996). Belirsiz cinsiyet rolü ise kadına ve erkeğe özgü özelliklerin her ikisinin de az miktarda bulunduğu (belirgin olmadığı) cinsiyet rolüdür (Mayer ve Sutton, 1996). Yapılan araştırmalara bakıldığında cinsiyet rollerinin birçok değiş̧kenle ilişkili olduğu görülmüştür. Cinsiyet rollerinin bireylerin benlik saygıları (Choi, 2004), stresle başa çıkma tarzları (Aydın, 2003), sosyal kaygı (Moscovitch, Hofmann ve Litz, 2004) ile ilişkili olduğu görülmüştür. Mahalik (2000) katı geleneksel sterotipik cinsiyet rolleri benimseyen erkeklerin bu rolleri kişilerarası ilişkilerinde kullandıkları ortaya çıkmıştır. Türkiye'de üniversite öğrencileri ile yapılan çalışmalara bakıldığında, erkek üniversite öğrencilerinin, kadın öğrencilere göre daha geleneksel toplumsal cinsiyet rollerine sahip olduğu görülmüş̧ür (Altuntaş ve Altınova, 2015; Kahraman, OzansoyTunçdemir ve Özcan, 2015; Vefikuluçay, Zeyneloğlu, Eroğlu ve Taşkın, 2007). Öngen ve Aytaç (2013) üniversite öğrencileri ile yaptıkları çalışmalarında kadın öğrencilerin erkek öğrencilere göre daha eşitlikçi toplumsal cinsiyet rollerine sahip oldukları, erkek öğrencilerin ise daha geleneksel cinsiyet rollerine sahip olduklarını ortaya koymuşlardır.

Aynı zamanda geleneksel cinsiyet rolleri ile kişiler arası ilişkilerde çatışma yönetimi, şiddet ailenin geliri, eğitim düzeyi ile ilişkili olduğu ortaya çıkmıştır (Kodan-Çetinkaya, 2013; Schwarzwald, Koslowsky ve Izhak-Nir, 2008). Çatışmalarda şiddetin yanı sıra olumlu duygu ve düşüncelerinde görülebileceği belirtilmektedir. Bu nedenle birey ve kişilerarası ilişkileri için çatışmanın faydalı sonuçlarının da olabileceği vurgulanmaktadır (Johnson ve Johnson, 2003). Çatışma insan yaşamında var olan normal bir durum olarak tanımlanmaktadır (Karip, 2010; Rahim, 2001). Çatışma çözme ise, bireyin ilişkilerinin sürdürülmesinde kullanılan önemli bir beceridir. Karip (2010) çatışma çözmeyi çatışmanın tarafları arasındaki uzlaşma ya da anlaşma ile sonuçlanması durumu olarak tanımlamaktadır. Johnson ve Johnson (2008) çatışma ile başa çıkmada beş temel boyutun olduğunu bunların; çatışmadan kaçınma, çatışmayı zorlama, çatışmayı kolaylaştırma, çatışmayı uzlaştırma ve çatışmaya karşı koyma olduğunu belirtmiştir. Uğurlu (2003) evli çiftlerle yaptığı çalışmasında, kadın ve erkeklerin farklı çatışma çözme stilleri kullandıklarını ortaya koymuştur. Erkeklerin olumsuz aktif çatışma yönetimini kullandıkları kadınların ise, olumsuz pasif çatışma yönetim biçimini kullandıkları ortaya çıkmıştır. Erkeklerin eğitim düzeyi düştükçe, çatışma ve düşmanca cinsiyetçiliğin arttığı ve olumsuz-aktif çatışma 
yönetim tarzını daha fazla kullandıkları ortaya çıkmıştır. Kadınlarda ise ailenin gelir düzeyi düştükçe, daha fazla olumsuz pasif çatışma yönetim tarzını kullandıkları ortaya çıkmıştır. Yapılan diğer çalışmalara bakıldığında da kadınların çatışma çözümünde problem hakkında konuşma ve geri çekilme gibi davranışları daha çok kullandıkları, erkeklerin ise, fiziksel zorlama, tehdit gibi yapıcı olmayan davranışları daha fazla kullandıkları ortaya çıkmıştır (Rose ve Azher, 1999; Tezer, 2001).

Yapılan çalışmalara bakıldığında romantik ilişki ile çatışma çözme arasında ilişki olduğunu göstermektedir. Böyle bir çalışmada Tüfekçi (2008) üniversite öğrencileri ile yaptığı çalışmada romantik ilişki sayısı ile güven ve çatışma arasında ilişki olduğunu, romantik ilişkisi olan öğrencilerin kendini daha az güvende hissettiği ve daha düşük oranda çatışma yaşadıklarını belirlemiştir. Bahadır (2006), yaşanan ilişki sayısı ile güven ve çatışma arasında negatif yönde anlamlı ilişkiler olduğunu saptamıştır. Yaşanan ilişkiler ve çatışma çözme arasında ilişkinin olması, her iki değişkenle de ilişkili olabilecek toplumsal cinsiyet rolleri ile de ilişkili olabileceğini düşündürmektedir. Nitekim üniversite öğrencileri ile yapılan çalışmalara bakıldığında toplumsal cinsiyet rolleri ile çatışma stillerinin bazı değişkenlere göre anlamlı bir şekilde farklılaştı̆̆ görülmüştür. Böyle bir çalışmada Sevim (2005) üniversite öğrencilerinin çatışma yaşamalarının cinsiyet ve toplumsal cinsiyet rollerine göre farklılıklar gösterdiğini ve kadın öğrencilerin daha uzlaşmacı olduğu ve erkek öğrencilerin ise daha hükmedici tarzları kullandığını saptamıştır. Tezer ve Demir (2001) üniversite öğrencileri üzerinde yaptıkları çalışmada kadın öğrencilerin aynı cinsten ve farklı cinsten arkadaşlarıyla ilişkilerinde aynı çatışma çözme stratejilerini kullandıkları, erkeklerin ise aynı cinsten arkadaşlarına karşı zorlama stratejisini kullandıkları, karşı cinsten arkadaşlarına ise kaçınma davranışını daha fazla tercih ettiklerini ortaya çıkarmışlardır.

Ergenliğin sonlarına doğru çatışmaları, bilişsel boyutunda gelişmesiyle birlikte yapıcı stratejilerle çözümlemek daha çok mümkün olmaktadır (Deutsch, 1994; Mayer, 2000). Dolayısıyla üniversite öğrencilerinin kişiler arası ilişkilerinde çatışma çözme stratejileri önemli hale gelmektedir. Özelliklede üniversite öğrencilerinin kişiler arası ilişkilerinde kullandıkları cinsiyet rollerine yönelik tutumların çatışma çözme arasındaki ilişkiyi incelemenin gerekli olduğu düşünülmektedir. Çünkü cinsiyet rollerine ilişkin tutumların çatışma çözme ile ilişkili olabileceği düşünülmektedir. $\mathrm{Bu}$ değişkenleri araştırmanın üniversite öğrencilerine yönelik sunulan psikolojik danışma hizmetlerinde yardımcı olabileceği düşünülmektedir. Dolayısıyla bu çalışmanın amacı üniversite öğrencilerinde toplumsal cinsiyet rolleri ve çatışma çözme arasındaki ilişkiyi incelemeyi amaçlamaktadır.

\section{Araştırmanın Amacı}

$\mathrm{Bu}$ araştırmanın amacı, üniversite öğrencilerinin toplumsal cinsiyet rolleri ile çatışma çözme stillerini incelemektir. Bu genel amaç çerçevesinde aşağıdaki soruları yanıt aranmıştır.

1. Üniversite öğrencilerinin toplumsal cinsiyet rolleri ile çatışma çözme stilleri cinsiyete göre farklılaşmakta mıdır?

2. Üniversite öğrencilerinin toplumsal cinsiyet rolleri ile çatışma çözme stilleri yakın bir arkadaşının olup olmamasına göre farklılaşmakta mıdır?

3. Üniversite öğrencilerinin toplumsal cinsiyet rolleri ile çatışma çözme stilleri daha önce romantik kadın/erkek arkadaşıyla bir ayrılık yaşamasına göre farklılaşmakta mıdır?

\section{Sinırlılıklar}

$\mathrm{Bu}$ araştırmanın bazı sınırlılıkları vardır. Bu çalışma çalışmanın yürütüldüğü çalışma grubunun özellikleri ile sınırlıdır. Ayrıca bulgular katılımcıların kendilerini algılamalarına dayandığından içtenlikle cevapladıkları düşünülmektedir. Araştırmanın bir diğer sınırlılığı ise bu çalışmada kullanılan ölçeklerin ölçtügü nitelikler ile sınırlı olmasıdır. 


\section{Yöntem}

\section{Araştırma Grubu}

Araştırmada Adıyaman Üniversitesine 2015-2016 eğitim-öğretim yılında devam eden 209'i erkek (\% 45,6) ve 249'u (\% 54,4) kadınlardan olmak üzere toplam 458 kişi ( $\bar{X}$ yaş=22,39, Sd=1,76, ranj= 19-37) çalışma grubunu oluşturmuştur. Çalışma grubunun oluşturulmasında kolay örneklem yöntemi kullanılmıştır. Araştırmanın çalışma grubuna 1.sınıflar alınmamıştır. 1. sınıfların alınmamasının nedeni henüz uyum sürecinde olmalarından kaynaklanmaktadır. Katılımcıların 25'i (\%5,5) 2.sınıf, 291'i (\% 63,5) 3. Sınıf ve 142'si (\%31) 4.sınıftan oluşmaktadır. Öğrencilerin 238'i (\% 52) Eğitim Fakültesinde, 173'i (\% 37,8) İktisadi ve İdari Bilimler Fakültesinde, 30’u (\% 6,6) Fen-Edebiyat Fakültesinde ve 17'si (\% 3,7) Mühendislik Fakültesinde öğrenimlerine devam etmektedir.

\section{Veri Toplama Araçları}

Toplumsal Cinsiyet Rolleri Tutum Ölçeği [TCRTÖ]: Ölçek Zeyneloğlu ve Terzioğlu (2011) tarafından geliştirilmiştir. Ölçek üniversite öğrencilerinin toplumsal cinsiyet rollerine ilişkin genel tutumlarını belirlemeye yöneliktir. Ölçekte toplam 38 madde ve beş alt boyutu içermektedir. $\mathrm{Bu}$ boyutlar, "eşitlikçi cinsiyet rolü", "kadinsı cinsiyet rolü", "evlilikte cinsiyet rolü", "geleneksel cinsiyet rolü" ve "erkeksi cinsiyet rolü"dür. Ölçek 5'li likert tipinde "tamamen katıllyor"=5 puan, "katılıyor" $=4$ puan, "kararsız"=3 puan, "katılmıyor" $=2$ puan, "kesinlikle katılmıyor" $=1$ puan olacak şekilde derecelendirilmektedir. Dolayısıyla puanlama 38-190, arasında değişmektedir. Ölçekten alınan en yüksek puan, bireyin toplumsal cinsiyet rollerine dair "eşitlikçi tutuma" sahip olduğunu, en düşük puan ise toplumsal cinsiyet rollerine ilişkin "geleneksel tutuma" sahip olduğunu ortaya çıkarmaktadır. Ölçeğin toplam Cronbach Alpfa güvenirlik katsayısının .92 olduğu ortaya çıkmıştır. Ölçeğin faktör yüklerinin .35 ile .79 arasında değiştiği saptanmıştır. Ölçeğin alt boyutlarının Cronbach Alpfa güvenirlik katsayısı .80-.72 arasında olduğu belirlenmiştir (Zeyneloğlu ve Terzioğlu, 2011). Üniversite öğrencileri ile yapılan bu çalışma kapsamında ölçeğin alt boyutlarının Cronbach Alfa iç güvenlik katsayılarının .71 ile .81 arasında olduğu saptanmıştır. Ölçeğin toplam Cronbach Alfa iç güvenlik katsayısının ise .91 olduğu saptanmıştır. Buna göre ölçeğin geçerli ve güvenilir olduğu söylenebilir.

Çatışma Eylem Stilleri Ölçeği [ÇESÖ]: Ölçek Johnson ve Johnson (2008) tarafından geliştirilmiş, Türkçe'ye Uyarlaması Karadağ ve Tosun (2014) tarafindan üniversite öğrencileri ile yapılmıştır. Ölçek bireylerin yaşadığı çatışmalara ilişkin eylem tarzını ortaya koymayı yöneliktir. Çatışma Eylem Stilleri Ölçeği; bireyin çatışma durumunda başa çıkmasına ilişkin davranış tarzının ortaya çıkarılması amacıyla geliştirilmiştir. Ölçeğin birçok dile uyarlandığı ve kullanıldığı belirtilmiştir. Ölçek maddelerinin tümü (35 madde) olumlu cümledir. Ölçekte toplam beş alt boyut bulunmaktadır. Ölçek 5'li Likert tipinde; Asla böyle davranmam=1, Nadiren böyle davranırım=2, Bazen böyle davranırım=3, Siklıkla böyle davranırım=4, Çoğunlukla böyle davranırım $=5$ şeklinde puanlandırılmaktadır. Alt boyutlardan alınan puanlar ise 5-35 arasında değişmektedir. Ölçek alt boyutlarından "Kaçınmacı Stil” yaşanan çatışmaların çözümünün umutsuz olduğuna inanmayı, amaçları ve ilişkiyi kesmeyi içermektedir. "Zorlayıcı stil" çatışma sürecinde, amacı ilişkilerden daha fazla önemsemeyi, "Kolaylaştırıcı stil" çatışmada ilişkileri korumak amacıyla çatışma ortamından ayrılmayı içermektedir. "Uzlaştırmacı Stil" çatışmada ortak bir yol bulmada çaba harcamayı ve "Karşı Koyucu stil" ise, çatışmada kişilere yararlı olacak çözümler araştırmayı içermektedir. Ölçek, bireylerin çatışmada baskın olan eylem stillerini ortaya çıkarmayı hedeflemektedir. Ölçekten alınabilecek toplam puan bulunmamaktadır. Ölçeğin geçerlik ve güvenirlik çalışmalarına bakıldığında ise Ki-kare $(\chi 2)$ ve istatistiki anlamlılık düzeyleri değerlerinin $[\chi 2=197.21, s d=138]$ şeklinde olduğu ortaya çıkmıştır. Uyum iyiliği indekslerinin ise [ $G F I=.91, A G F I=.88, R M S E A=.05]$ olduğu saptanmıştır. Sonuçta beş alt boyuta yönelik ölçülen değişkenlerin, orijinalinde de yer alan alt boyutların altında yer aldığ görülmüş̧ür. Yapılan doğrulayıcı faktör analizinde elde edilen faktör yüklerinin ise.47 -.83 
arasında olduğu ortaya çıkmıştır. Ölçeğin iç tutarlı1ık katsayısı Cronbach Alpha değerlerinin alt ölçekler açısından .72- .79 arasında olduğu ortaya çıkmıştır. Ölçeğin alt boyutlarına ilişkin Guttman yarımlar katsayısı değerlerinin ise, .71- .81 arasında olduğu belirtilmiştir (Karadağ ve Tosun, 2014). Üniversite öğrencileri ile yapılan bu çalışma kapsamında ölçeğin alt boyutlarına ait Cronbach Alpha değerlerinin ise .71- .77 arasında olduğu ortaya çıkmıştır. Buna göre ölçeğin geçerli ve güvenilir olduğu söylenebilir.

\section{Kişisel Bilgi Formu}

Araştırmada bireye özgü kişisel değişkenleri ortaya koymak amacıyla araştırmacı tarafindan "Kişisel Bilgi Formu” geliştirilmiştir. Bağımsız değişkenlere ilişkin formda yaş, cinsiyet, fakülte, sınıf düzeyi ve romantik bir beraberliği olup olmadığ ayrılık yaşayıp yaşamadığına yönelik çeşitli sorular yer almıştır.

\section{Verilerin Analizi}

Verilerin analizinde betimleyici istatistik, Pearson Momentler Çarpımı Korelasyonu, Tek Yönlü ANOVA ve post-hoc çoklu karşılaştırma testlerinden Tukey HSD testi kullanılmıştır. Bu testin kullanılma nedeni grup ortalamaları arasında anlamlı bir farklılığın olup olmadığını belirlemektir. Ortalamalar arasındaki farkın anlamlı olup olmadığını belirlemek için .05 önem düzeyi esas alınmıştır.

Nicel araştırmalarda verilerin analizine geçmeden önce normallik varsayımları ve uç değerlerin kontrol edilmesi gerekmektedir. Buna göre ölçeklerin basıklık (-.03 ile -.63 arasında) ve çarpıklık (-.003 ile .58 arasında) puanlarının olduğu ortaya çıkmıştır. Tabachnick ve Fidell'e (2013) göre bir veri setinin normal olduğunun kabul edilmesinin ölçütlerinden biri olarak basıklık ve çarpıklık değerlerinin +1 ile -1 arasında olması gerekmektedir. Buna göre verinin normal dağıldığı görülmüştür. Tek Yönlü ANOVA'nın analizde kullanılabilmesi için veride "doğrusallık" ve "normallik" sayıltılarının karşılanması gerekmektedir. Buna göre uç değerlerin saptanması için Mahalanobis uzaklık değerleri hesaplanmıştır. Uç değer analizi için hesaplanan Mahalanobis değeri, bulunan tablo değerinden küçük ise, çok değişkenli normallik varsayımının karşılandığ 1 bilinmektedir. Ki kare tablo değerinin üzerinde bir Mahalanobis değerine sahip olan veriler ise, uç değer olarak belirlenerek veri setinden çıkartılması gerekmektedir. Bunun için .001 manidarlık düzeyinin alınması gerektiği belirtilmektedir (Büyüköztürk, 2004). Buna göre uç değere sahip olan 29 katılımcının verisi setten çıkarılmıştır. Ayrıca saçılım grafiğine bakıldığında da doğrusal bir ilişkinin olduğu saptanmıştır. Ayrıca nicel araştırmalarda Tek Yönlü ANOVA’nın kullanılabilmesi için varyansların homojen dağılması gerekmektedir. Varyansların homojenliğine ilişkin yapılan Levene testine bakıldığında veride varyansların homojenliğinin sağlandığı görülmüştür $(\mathrm{p}>$.05). Dolayısıyla Tek yönlü ANOVA'nın varsayımlarının karşılandığ görülmüştür.

\section{Bulgular}

Araştırmada üniversite öğrencilerinin ölçeklerden aldıkları puanların tanımlayıcı istatistikleri Tablo 1'de verilmiştir. Araştırmadaki değişkenler arasındaki korelasyon değerleri de Tablo 1'de sunulmuştur.

Tablo 1

Araştırmadaki Değişkenlere İlişkin Betimleyici İstatistikler ve Pearson Korelasyon Katsayısı Değerleri

\begin{tabular}{|c|c|c|c|c|c|c|c|c|c|c|c|c|c|c|}
\hline Değişkenler & & & $\bar{X}$ & Ss & 1 & 2 & 3 & 4 & 5 & 6 & 7 & 8 & 9 & 10 \\
\hline \multirow{3}{*}{$\begin{array}{l}\text { 1.Eşitlikçi } \\
\text { cinsiyet rolü }\end{array}$} & Kadın & 249 & 12,36 & 3,52 & & & & & & & & & & \\
\hline & Erkek & 209 & 15,83 & 4,29 & & & & & & & & & & \\
\hline & Toplam & 458 & 13,94 & 4,25 & - & & & & & & & & & \\
\hline \multirow{2}{*}{$\begin{array}{l}\text { 2.Kadınsı } \\
\text { cinsiyet rolü }\end{array}$} & $\begin{array}{l}\text { Kadın } \\
\text { Erkek }\end{array}$ & $\begin{array}{l}249 \\
209\end{array}$ & $\begin{array}{l}23,09 \\
27,53\end{array}$ & $\begin{array}{l}5,82 \\
5,86\end{array}$ & & & & & & & & & & \\
\hline & Toplam & 458 & 25,12 & 6,24 &, $52 * *$ & & & & & & & & & \\
\hline
\end{tabular}


Büyükşahin Çevik

\begin{tabular}{|c|c|c|c|c|c|c|c|c|c|c|c|c|c|c|}
\hline \multirow{3}{*}{$\begin{array}{l}\text { 3.Evlilikte } \\
\text { cinsiyet rolü }\end{array}$} & Kadın & 249 & 12,3 & 3,46 & \multirow{4}{*}{, $60 * *$} & \multirow[b]{3}{*}{, $55 * *$} & \multirow[b]{3}{*}{-} & \multirow[b]{3}{*}{. } & & & & & & \\
\hline & Erkek & 209 & 16,04 & 4,28 & & & & & & & & & & \\
\hline & Toplam & 458 & 14,01 & 4,28 & & & & & & & & & & \\
\hline \multirow{3}{*}{$\begin{array}{l}\text { 4.Geleneksel } \\
\text { cinsiyet rolü }\end{array}$} & Kadın & 249 & 20,89 & 5,74 & & & & & & & & & & \\
\hline & Erkek & 209 & 26,6 & 6,19 & & & & & & & & & & \\
\hline & Toplam & 458 & 23,49 & 6,59 &, $49 * *$ &, $73 * *$ & ,63 & - & & & & & & \\
\hline \multirow{3}{*}{$\begin{array}{l}\text { 5.Erkeksi } \\
\text { cinsiyet rolü }\end{array}$} & Kadın & 249 & 12,1 & 3,84 & \multirow[b]{3}{*}{$.46^{* *}$} & \multirow[b]{3}{*}{, $61 * *$} & \multirow[b]{3}{*}{, $60 * *$} & \multirow[b]{3}{*}{, $68 * *$} & \multirow[b]{3}{*}{-} & & & & & \\
\hline & Erkek & 209 & 14,54 & 4,12 & & & & & & & & & & \\
\hline & Toplam & 458 & 13,22 & 4,15 & & & & & & & & & & \\
\hline \multirow{3}{*}{$\begin{array}{l}\text { 6.Toplumsal } \\
\text { Cinsiyet } \\
\text { rolleri }\end{array}$} & Kadın & 249 & 80,76 & 17,88 & & \multirow[b]{3}{*}{, $86^{* *}$} & & & & & & & & \\
\hline & Erkek & 209 & 100,55 & 19,74 & \multirow[b]{2}{*}{, $72 * *$} & & \multirow[b]{2}{*}{, $80 * *$} & \multirow[b]{2}{*}{$.89 * *$} & \multirow[b]{2}{*}{, $80 * *$} & & & & & \\
\hline & Toplam & 458 & 89,79 & 21,17 & & & & & & - & & & & \\
\hline \multirow{3}{*}{$\begin{array}{l}\text { 7.Çatışmadan } \\
\text { Kaçınma }\end{array}$} & Kadın & 249 & 20,93 & 3,64 & \multirow[b]{3}{*}{,021 } & \multirow{4}{*}{, $16 * *$} & \multirow[b]{3}{*}{, $16 * *$} & & & & & & & \\
\hline & Erkek & 209 & 20,75 & 3,39 & & & & \multirow[b]{2}{*}{, $21 * *$} & \multirow[b]{2}{*}{, $21 * *$} & \multirow[b]{2}{*}{, $19 * *$} & \multirow[b]{2}{*}{ - } & & & \\
\hline & Toplam & 458 & 20,85 & 3,52 & & & & & & & & & & \\
\hline \multirow{3}{*}{$\begin{array}{l}\text { 8.Çatışmayı } \\
\text { Zorlama }\end{array}$} & Kadın & 249 & 24,55 & 3,02 & \multirow{4}{*}{,- 086} & & & & & & & & & \\
\hline & Erkek & 209 & 24,71 & 2,8 & & & & & & & & & & \\
\hline & Toplam & 458 & 24,62 & 2,92 & & ,06 & ,03 &, $10^{*}$ &, $11 *$ & ,06 &, $28 * *$ & - & & \\
\hline & Kadın & 249 & 26,63 & 3,34 & & & & & & & & & & \\
\hline 9.Çatışmayı & Erkek & 209 & 26,50 & 3,34 & & & & & & & & & & \\
\hline Kolaylaştırma & Toplam & 458 & 26,57 & 3,34 & , $17 * *$ & ,03 &,- 05 & ,07 & ,03 &,- 008 &, $18 * *$ &, $31 * *$ & - & \\
\hline & $\begin{array}{l}\text { Kadın } \\
\text { Erkek }\end{array}$ & $\begin{array}{l}249 \\
209\end{array}$ & $\begin{array}{l}25,8 \\
25,6\end{array}$ & $\begin{array}{l}2,95 \\
3,16\end{array}$ & & & & & & & & & & \\
\hline uzlaştırma & & & & & - &, $12 * *$ & & & & & & & & \\
\hline & Toplam & 458 & 25,71 & 3,05 &, $12 * *$ & & ,02 &, $17 * *$ &, $15^{* *}$ &, $10^{*}$ &, $22 * *$ &, $31 * *$ &, $47 * *$ & \\
\hline 11.Çatışmaya & $\begin{array}{l}\text { Kadın } \\
\text { Erkek }\end{array}$ & $\begin{array}{l}249 \\
209\end{array}$ & $\begin{array}{l}26,01 \\
26,12\end{array}$ & $\begin{array}{l}2,68 \\
2,71\end{array}$ & & & & & & & & & & \\
\hline Karşı Koyma & Toplam & 458 & 26,06 & 2,69 & $25^{* *}$ &,- 07 & - $111^{-}$ &,- 04 &,- 001 &,$- 10^{*}$ &, $19 * *$ &, $33 * *$ &, $36 * *$ &, $41 * *$ \\
\hline
\end{tabular}

Tablo 1'e bakıldığında eşitlikçi cinsiyet rolü ortalamasının $(\bar{X}=13,94)$ olduğu, kadınsı cinsiyet rolünün ( $\bar{X}=25,12)$, evlilikte cinsiyet rolünün $(\bar{X}=14,01)$, geleneksel cinsiyet rolünün ( $\bar{X}=23,49)$, erkeksi cinsiyet rolünün $(\bar{X}=13,22)$, toplumsal cinsiyet rolünün $(\bar{X}=89,79)$ olduğu görülmüştür. Çatışma stillerinden çatışmadan kaçınmacı stilinin ortalamasının $(\bar{X}=20,85)$, çatışmayı zorlayıcı ( $\bar{X}=24,62$ ), çatışmayı kolaylaştırıcı ( $\bar{X}=26,57)$, çatışmayı uzlaştırmacı ( $\bar{X}$ $=25,71)$ ve çatışmaya karşı koyucu $(\bar{X}=26,06)$ stilinin ortalamalarının olduğu görülmüştür. Korelasyon değerlerine bakıldığında cinsiyet rolleri ölçeklerinin pozitif yönde ilişkili olduğu, eşitlikçi cinsiyet rolünün çatışmadan kaçınmacı stil ile pozitif yönde diğer çatışma stilleri ile negatif yönde ilişkili olduğu, kadın cinsiyet rolünün çatışmaya karşı koyucu stili ile negatif yönde diğer çatışma stilleri ile pozitif yönde ilişkili olduğu ortaya çıkmıştır. Evlilikte cinsiyet rolünün çatışmayı kolaylaştırıcı ve çatışmaya karşı koyucu stilleri ile negatif yönde diğer stilleri ile pozitif yönde ilişkili olduğu ortaya çıkmıştır. Geleneksel cinsiyet rolleri ile erkek cinsiyet rollerinin çatışmaya karşı koyucu rol ile negatif yönde diğer stiller ile pozitif yönde ilişkili olduğu ortaya çıkmıştır. Toplumsal cinsiyet rollerinin ise çatışmayı kolaylaştırıcı ve çatışmaya karşı koyucu stiller ile negatif yönde diğer stiller ile pozitif yönde ilişkili olduğu ortaya çıkmıştır.

Tablo 2'de Cinsiyete göre toplumsal cinsiyet rolleri ve çatışma çözme stillerine ilişkin tek yönlü ANOVA sonuçları verilmiştir. 
Üniversite Öğrencilerinin Toplumsal Cinsiyet Rolleri ve Çatışma Çözme Stillerinin İncelenmesi

Tablo 2

Cinsiyete Göre Toplumsal Cinsiyet Rolleri ve Çatışma Çözme Stillerine İlişkin Tek Yönlü ANOVA Sonuçları

\begin{tabular}{|c|c|c|c|c|c|c|}
\hline & & $\begin{array}{l}\text { Kareler } \\
\text { Toplamı }\end{array}$ & $\mathrm{df}$ & $\begin{array}{l}\text { Kareler } \\
\text { Ortalamas1 }\end{array}$ & $\mathrm{F}$ & $\mathrm{P}$ \\
\hline \multirow{3}{*}{$\begin{array}{l}\text { Eşitlikçi cinsiyet } \\
\text { rolü }\end{array}$} & Gruplar arası & 1365,86 & 1 & 1365,86 & 89,99 &, 000 \\
\hline & Gruplar içi & 6920,88 & 456 & 15,17 & & \\
\hline & Toplam & 8286,74 & 457 & & & \\
\hline \multirow{3}{*}{$\begin{array}{l}\text { Kadınsı cinsiyet } \\
\text { rolü }\end{array}$} & Gruplar arası & 2243,53 & 1 & 2243,53 & 65,68 &, 000 \\
\hline & Gruplar içi & 15574,85 & 456 & 34,15 & & \\
\hline & Toplam & 17818,39 & 457 & & & \\
\hline \multirow{3}{*}{$\begin{array}{l}\text { Evlilikte cinsiyet } \\
\text { rolü }\end{array}$} & Gruplar aras1 & 1584,12 & 1 & 1584,12 & 106,07 & ,000 \\
\hline & Gruplar içi & 6809,8 & 456 & 14,93 & & \\
\hline & Toplam & 8393,92 & 457 & & & \\
\hline \multirow{3}{*}{$\begin{array}{l}\text { Geleneksel cinsiyet } \\
\text { rolü }\end{array}$} & Gruplar arası & 3706,38 & 1 & 3706,38 & 104,62 & ,000 \\
\hline & Gruplar içi & 16154,11 & 456 & 35,42 & & \\
\hline & Toplam & 19860,49 & 457 & & & \\
\hline \multirow{3}{*}{$\begin{array}{l}\text { Erkeksi cinsiyet } \\
\text { rolü }\end{array}$} & Gruplar arası & 674,83 & 1 & 674,83 & 42,74 &, 000 \\
\hline & Gruplar içi & 7199,89 & 456 & 15,78 & & \\
\hline & Toplam & 7874,72 & 457 & & & \\
\hline \multirow{3}{*}{$\begin{array}{l}\text { Toplumsal Cinsiyet } \\
\text { rolleri }\end{array}$} & Gruplar aras1 & 44513,52 & 1 & 44513,52 & 126,51 & ,000 \\
\hline & Gruplar içi & 160435,99 & 456 & 351,83 & & \\
\hline & Toplam & 204949,52 & 457 & & & \\
\hline \multirow{3}{*}{$\begin{array}{l}\text { Çatışmadan } \\
\text { Kaçınma }\end{array}$} & Gruplar arası & 3,83 & 1 & 3,83 &, 3 & ,579 \\
\hline & Gruplar içi & 5680,65 & 456 & 12,45 & & \\
\hline & Toplam & 5684,48 & 457 & & & \\
\hline \multirow[t]{3}{*}{ Çatışmayı Zorlama } & Gruplar arası & 3,03 & 1 & 3,03 &, 35 &, 552 \\
\hline & Gruplar içi & 3909,86 & 456 & 8,57 & & \\
\hline & Toplam & 3912,9 & 457 & & & \\
\hline \multirow{3}{*}{$\begin{array}{l}\text { Çatışmayı } \\
\text { Kolaylaştırma }\end{array}$} & Gruplar arası & 1,84 & 1 & 1,84 & ,16 & ,685 \\
\hline & Gruplar içi & 5097,98 & 456 & 11,18 & & \\
\hline & Toplam & 5099,82 & 457 & & & \\
\hline \multirow{3}{*}{$\begin{array}{l}\text { Çatışmayı } \\
\text { uzlaştırma }\end{array}$} & Gruplar arası & 4,52 & 1 & 4,52 & ,48 & ,486 \\
\hline & Gruplar içi & 4250,57 & 456 & 9,32 & & \\
\hline & Toplam & 4255,1 & 457 & & & \\
\hline \multirow{3}{*}{$\begin{array}{l}\text { Çatışmaya Karşı } \\
\text { Koyma }\end{array}$} & Gruplar arası & 1,55 & 1 & 1,55 &, 21 & ,644 \\
\hline & Gruplar içi & 3324,47 & 456 & 7,29 & & \\
\hline & Toplam & 3326,03 & 457 & & & \\
\hline
\end{tabular}

Tablo 2'ye bakıldığında cinsiyete göre çatışma stillerinin anlamlı derecede farklılaşmadığı ( $>0.05)$, buna karşılık cinsiyet rollerinin bütün alt ölçeklerinin anlamlı derecede farklılaştığı görülmüştür. Farkın hangi gruplar arasında olduğuna bakıldığında ise, eşitlikçi cinsiyet rolünün $[\mathrm{F}(1-456)=89,99, \mathrm{p}<.05]$ erkeklerde ortalamasının $(\bar{X}=15,83)$ kadınlara $(\bar{X}$ $=12,36$ ) oranla anlamlı olarak daha yüksek olduğu ortaya çıkmıştır. Benzer olarak kadınsı cinsiyet rolünün $[\mathrm{F}(1-456)=65,68, \mathrm{p}<.05]$ erkeklerde ortalamasının $(\bar{X}=27,53)$ kadınlara $(\bar{X}=23,09)$ 
oranla anlamlı olarak daha yüksek olduğu ortaya çıkmıştır. Evlilikte cinsiyet rolünün $[\mathrm{F}(1-456)=$ $106,07, \mathrm{p}<.05]$ erkeklerde ortalamasinın ( $\bar{X}=16,04)$ kadınlara $(\bar{X}=12,3)$ oranla anlamlı olarak daha yüksek olduğu ortaya çıkmıştır. Geleneksel cinsiyet rolünün $[F(1-456)=104,62, p<.05]$ erkeklerde ortalamasının $(\bar{X}=26,6)$ kadınlara $(\bar{X}=20,89)$ oranla anlamlı olarak daha yüksek olduğu ortaya çıkmıştır. Erkeksi cinsiyet rolünün $[\mathrm{F}(1-456)=104,62, \mathrm{p}<.05]$ erkeklerde ortalamasının ( $\bar{X}=14,54)$ kadınlara ( $\bar{X}=12,1)$ oranla anlamlı olarak daha yüksek olduğu ortaya çıkmıştır. Toplumsal cinsiyet rolünün $[\mathrm{F}(1-456)=126,51, \mathrm{p}<.05]$ erkeklerde ortalamasının $(\bar{X}$ $=100,55)$ kadınlara $(\bar{X}=80,76)$ oranla anlamlı olarak daha yüksek olduğu ortaya çıkmıştır.

Üniversite öğrencilerinin yakın bir ilişkisi (romantik kadın/erkek) olmasına ilişkin betimleyici istatistikler Tablo 3'de verilmiştir.

Tablo 3

Üniversite Öğrencilerinin Yakın Bir İlişkisi Olmasına İlişkin Betimleyici İstatistikler

\begin{tabular}{|c|c|c|c|c|}
\hline & & & $\bar{X}$ & Ss \\
\hline \multirow[t]{3}{*}{ Eşitlikçi cinsiyet rolü } & Evet & 211 & 13,24 & 4,17 \\
\hline & Hayır & 247 & 14,54 & 4,24 \\
\hline & Toplam & 458 & 13,94 & 4,25 \\
\hline \multirow[t]{3}{*}{ Kadınsı cinsiyet rolü } & Evet & 211 & 23,68 & 6,43 \\
\hline & Hayır & 247 & 26,34 & 5,81 \\
\hline & Toplam & 458 & 25,12 & 6,24 \\
\hline \multirow{3}{*}{ Evlilikte cinsiyet rolü } & Evet & 211 & 13,65 & 4,26 \\
\hline & Hayır & 247 & 14,31 & 4,29 \\
\hline & Toplam & 458 & 14,01 & 4,28 \\
\hline \multirow{3}{*}{ Geleneksel cinsiyet rolü } & Evet & 211 & 23,13 & 6,68 \\
\hline & Hayır & 247 & 23,8 & 6,5 \\
\hline & Toplam & 458 & 23,49 & 6,59 \\
\hline \multirow[t]{3}{*}{ Erkeksi cinsiyet rolü } & Evet & 211 & 12,97 & 4,19 \\
\hline & Hayır & 247 & 13,43 & 4,11 \\
\hline & Toplam & 458 & 13,22 & 4,15 \\
\hline \multirow{3}{*}{ Toplumsal Cinsiyet rolleri } & Evet & 211 & 86,69 & 21,66 \\
\hline & Hayır & 247 & 92,45 & 20,41 \\
\hline & Toplam & 458 & 89,79 & 21,17 \\
\hline \multirow{3}{*}{ Çatışmadan Kaçınma } & Evet & 211 & 20,9 & 3,34 \\
\hline & Hayır & 247 & 20,81 & 3,68 \\
\hline & Toplam & 458 & 20,85 & 3,5 \\
\hline \multirow{3}{*}{ Çatışmayı Zorlama } & Evet & 211 & 24,77 & 2,9 \\
\hline & Hayır & 247 & 24,5 & 2,94 \\
\hline & Toplam & 458 & 24,62 & 2,92 \\
\hline \multirow{3}{*}{ Çatışmayı Kolaylaştırma } & Evet & 211 & 26,55 & 3,44 \\
\hline & Hayır & 247 & 26,59 & 3,25 \\
\hline & Toplam & 458 & 26,57 & 3,34 \\
\hline \multirow{3}{*}{ Çatışmayı uzlaştırma } & Evet & 211 & 25,75 & 3,05 \\
\hline & Hayır & 247 & 25,68 & 3,05 \\
\hline & Toplam & 458 & 25,71 & 3,05 \\
\hline \multirow{3}{*}{ Çatışmaya Karşı Koyma } & Evet & 211 & 26,14 & 2,59 \\
\hline & Hayır & 247 & 26 & 2,78 \\
\hline & Toplam & 458 & 26,06 & 2,69 \\
\hline
\end{tabular}


Tablo 3'e bakıldığında üniversite öğrencilerinin yakın bir ilişkisi (romantik kadın/erkek) olan öğrencilerin eşitlikçi cinsiyet rolü ortalamasının $(\bar{X}=13,24)$ olmayanlara göre $(\bar{X}=14,54)$ daha düşük olduğu görülmüştür. Öğrencilerden yakın bir ilişkisi (romantik kadın/erkek) olan öğrencilerin (evet) kadınsı cinsiyet rolünün ( $\bar{X}=23.68)$, olmayanlara (hayır) göre $(\bar{X}=26,34)$ daha düşük olduğu görülmüştür. Yakın bir ilişkisi (romantik kadın/erkek) olan öğrencilerin evlilikte cinsiyet rolünün $(\bar{X}=13,65)$ olmayanlara göre $(\bar{X}=14,31)$ daha düşük olduğu saptanmıştır. Yakın bir ilişkisi (romantik kadın/erkek) olan öğrencilerin geleneksel cinsiyet rolünün ( $\bar{X}=23,13)$ olmayanlara göre $(\bar{X}=23,8)$ daha düşük olduğu ortaya çıkmıştır. Yakın bir ilişkisi (romantik kadın/erkek) olan öğrencilerin erkeksi cinsiyet rolünün $(\bar{X}=12,97$ olmayanlara göre ( $\bar{X}=13,43)$ daha düşük olduğu ortaya çıkmıştır. Yakın bir ilişkisi (romantik kadın/erkek) olan ögrencilerin toplumsal cinsiyet rolleri ortalamasının $(\bar{X}=86,69)$ olmayanlara göre $(\bar{X}$ $=92,45)$ daha düşük düzeyde olduğu görülmüştür. Yakın bir ilişkisi (romantik kadın/erkek) olan öğrencilerin çatışmadan kaçınmacı stili ortalamasının $(\bar{X}=20,9)$ olmayanlara göre $(\bar{X}=20,81)$ daha yüksek olduğu ortaya çıkmıştır. Yakın bir ilişkisi (romantik kadın/erkek) olan öğrencilerin çatışmayı zorlayıcı ortalamalarının ( $\bar{X}=24,77)$ olmayanlara göre ( $\bar{X}=24,5)$ daha yüksek olduğu ortaya çıkmıştır. Yakın bir ilişkisi (romantik kadın/erkek) olan öğrencilerin çatışmayı kolaylaştırıcı ortalamalarının ( $\bar{X}=26,55)$ olmayanlara göre $(\bar{X}=26,59)$ daha düşük olduğu görülmüştür. Yakın bir ilişkisi (romantik kadın/erkek) olan öğrencilerin çatışmayı uzlaştırmacı ortalamalarının ( $\bar{X}=25,75)$ olmayanlara göre $(\bar{X}=25,68)$ daha düşük olduğu görülmüştür. Yakın bir ilişkisi (romantik kadın/erkek) olan öğrencilerin çatışmaya karşı koyucu ortalamalarının ( $\bar{X}$ $=26,14)$ olmayanlara göre $(\bar{X}=26)$ daha yüksek olduğu görülmüştür.

Üniversite öğrencilerinin yakın bir ilişsisi (romantik kadın/erkek) olmasına ilişkin Tek yönlü ANOVA sonuçları Tablo 4'de verilmiştir. 
Tablo 4

Üniversite Öğrencilerinin Yakın Bir İlişkisi (Romantik Kadın/Erkek) Olmasına İlişkin Tek Yönlü ANOVA Sonuçları

\begin{tabular}{|c|c|c|c|c|c|c|}
\hline & & $\begin{array}{l}\text { Kareler } \\
\text { toplam } 1\end{array}$ & df & $\begin{array}{l}\text { Kareler } \\
\text { ortalamas1 }\end{array}$ & $\mathrm{F}$ & $\mathrm{P}$ \\
\hline \multirow{3}{*}{$\begin{array}{l}\text { Eşitlikçi cinsiyet } \\
\text { rolü }\end{array}$} & Gruplar arası & 192,34 & 1 & 192,34 & 10,83 & ,001 \\
\hline & Gruplar içi & 8094,39 & 456 & 17,75 & & \\
\hline & Toplam & 8286,74 & 457 & & & \\
\hline \multirow{3}{*}{$\begin{array}{l}\text { Kadınsı cinsiyet } \\
\text { rolü }\end{array}$} & Gruplar arası & 808,61 & 1 & 808,61 & 21,67 & ,000 \\
\hline & Gruplar içi & 17009,78 & 456 & 37,3 & & \\
\hline & Toplam & 17818,39 & 457 & & & \\
\hline \multirow{3}{*}{$\begin{array}{l}\text { Evlilikte cinsiyet } \\
\text { rolü }\end{array}$} & Gruplar arası & 50,44 & 1 & 50,44 & 2,75 & ,098 \\
\hline & Gruplar içi & 8343,47 & 456 & 18,29 & & \\
\hline & Toplam & 8393,92 & 457 & & & \\
\hline \multirow{3}{*}{$\begin{array}{l}\text { Geleneksel } \\
\text { cinsiyet rolü }\end{array}$} & Gruplar arası & 50,81 & 1 & 50,81 & 1,17 & ,280 \\
\hline & Gruplar içi & 19809,68 & 456 & 43,44 & & \\
\hline & Toplam & 19860,49 & 457 & & & \\
\hline \multirow{3}{*}{$\begin{array}{l}\text { Erkeksi cinsiyet } \\
\text { rolü }\end{array}$} & Gruplar arası & 24,25 & 1 & 24,25 & 1,4 & ,236 \\
\hline & Gruplar içi & 7850,47 & 456 & 17,21 & & \\
\hline & Toplam & 7874,72 & 457 & & & \\
\hline \multirow{3}{*}{$\begin{array}{l}\text { Toplumsal } \\
\text { cinsiyet rolü }\end{array}$} & Gruplar arası & 3777,32 & 1 & 3777,32 & 8,56 & ,004 \\
\hline & Gruplar içi & 201172,19 & 456 & 441,16 & & \\
\hline & Toplam & 204949,52 & 457 & & & \\
\hline \multirow{3}{*}{$\begin{array}{l}\text { Çatışmadan } \\
\text { kaçınma }\end{array}$} & Gruplar arası & ,95 & 1 & ,95 & ,07 & ,782 \\
\hline & Gruplar içi & 5683,53 & 456 & 12,46 & & \\
\hline & Toplam & 5684,48 & 457 & & & \\
\hline \multirow{3}{*}{$\begin{array}{l}\text { Çatışmayı } \\
\text { zorlama }\end{array}$} & Gruplar arası & 8,62 & 1 & 8,62 & 1 & ,316 \\
\hline & Gruplar içi & 3904,28 & 456 & 8,56 & & \\
\hline & Toplam & 3912,9 & 457 & & & \\
\hline \multirow{3}{*}{$\begin{array}{l}\text { Çatışmayı } \\
\text { kolaylaştırma }\end{array}$} & Gruplar arası &, 11 & 1 &, 11 & ,01 & ,919 \\
\hline & Gruplar içi & 5099,71 & 456 & 11,18 & & \\
\hline & Toplam & 5099,82 & 457 & & & \\
\hline \multirow{3}{*}{$\begin{array}{l}\text { Çatışmayı } \\
\text { uzlaştırma }\end{array}$} & Gruplar arası &, 69 & 1 & ,69 & ,07 & ,785 \\
\hline & Gruplar içi & 4254,4 & 456 & 9,33 & & \\
\hline & Toplam & 4255,1 & 457 & & & \\
\hline \multirow{3}{*}{$\begin{array}{l}\text { Çatışmaya karşı } \\
\text { koyma }\end{array}$} & Gruplar arası & 2,3 & 1 & 2,30 & ,31 & ,575 \\
\hline & Gruplar içi & 3323,73 & 456 & 7,28 & & \\
\hline & Toplam & 3326,03 & 457 & & & \\
\hline
\end{tabular}

Tablo 4'e bakıldığında üniversite öğrencilerinin yakın bir ilişkisi (romantik kadın/erkek) olmasına göre çatışma sitllerinin ve evlilikte cinsiyet, geleneksel cinsiyet ve erkeksi cinsiyet rollerinin anlamlı olarak farklılaşmadığı $(\mathrm{p}>0.05)$ görülmüştür. Buna karşılık eşitlikçi cinsiyet rolünün anlamlı olarak farklılaştığ $[\mathrm{F}(1-456)=10,83, \mathrm{p}<.05]$ görülmüştür. Farkın hangi gruplar arasında olduğuna bakıldığında üniversite öğrencilerinin yakın bir ilişkisi (romantik kadın/erkek) olanların ( $\bar{X}=13,24)$ olmayanlara göre ( $\bar{X}=14,54)$ anlamlı olarak daha düşük düzeyde olduğu görülmüştür. Kadınsı cinsiyet rolününde anlamlı olarak farklılaştığ $[F(1-456)=808,61, \mathrm{p}<.05]$ 
görülmüştür. Farkın hangi gruplar arasında olduğuna bakıldığında üniversite öğrencilerinin yakın bir ilişkisi (romantik kadın/erkek) olanların kadınsı cinsiyet rolü ortalamasının ( $\bar{X}=23,68)$ olmayanlara göre ( $\bar{X}=26,34)$ anlamlı olarak daha düşük düzeyde olduğu görülmüştür. Toplumsal cinsiyet rolünün de anlamlı olarak farklılaştığı $[\mathrm{F}(1-456)=8,56, \mathrm{p}<.05]$ görülmüsstür. Yakın bir ilişkisi (romantik kadın/erkek) olan öğrencilerin toplumsal cinsiyet rolleri ortalamasının ( $\bar{X}$ $=86,69)$ olmayanlara göre ( $\bar{X}=92,45)$ anlamlı olarak daha düşük düzeyde olduğu görülmüştür.

Üniversite öğrencilerinin daha önce romantik kadın/erkek arkadaşıyla bir ayrllık yaşamasına ilişkin betimleyici istatistikler Tablo 5 'de verilmiştir.

Tablo 5

Üniversite Öğrencilerinin Daha Önce Romantik Kadın/Erkek Arkadaşıyla Bir Ayrılık Yaşamasına İlişkin Betimleyici İstatistikler

\begin{tabular}{|c|c|c|c|c|}
\hline & & & $\bar{X}$ & Ss \\
\hline \multirow[t]{3}{*}{ Eşitlikçi cinsiyet rolü } & Evet & 236 & 13,85 & 4,38 \\
\hline & Hayır & 222 & 14,04 & 4,13 \\
\hline & Toplam & 458 & 13,94 & 4,25 \\
\hline \multirow[t]{3}{*}{ Kadınsı cinsiyet rolü } & Evet & 236 & 24,33 & 6,66 \\
\hline & Hayır & 222 & 25,95 & 5,66 \\
\hline & Toplam & 458 & 25,12 & 6,24 \\
\hline \multirow[t]{3}{*}{ Evlilikte cinsiyet rolü } & Evet & 236 & 14,26 & 4,44 \\
\hline & Hayır & 222 & 13,74 & 4,1 \\
\hline & Toplam & 458 & 14,01 & 4,28 \\
\hline \multirow[t]{3}{*}{ Geleneksel cinsiyet rolü } & Evet & 236 & 23,51 & 6,76 \\
\hline & Hayır & 222 & 23,47 & 6,42 \\
\hline & Toplam & 458 & 23,49 & 6,59 \\
\hline \multirow[t]{3}{*}{ Erkeksi cinsiyet rolü } & Evet & 236 & 13,15 & 4,4 \\
\hline & Hayır & 222 & 13,28 & 3,86 \\
\hline & Toplam & 458 & 13,22 & 4,15 \\
\hline \multirow[t]{3}{*}{ Toplumsal cinsiyet rolü } & Evet & 236 & 89,13 & 22,2 \\
\hline & Hayır & 222 & 90,5 & 20,05 \\
\hline & Toplam & 458 & 89,79 & 21,17 \\
\hline \multirow[t]{3}{*}{ Çatışmadan kaçınma } & Evet & 236 & 20,77 & 3,47 \\
\hline & Hayır & 222 & 20,94 & 3,58 \\
\hline & Toplam & 458 & 20,85 & 3,52 \\
\hline \multirow[t]{3}{*}{ Çatışmayı zorlama } & Evet & 236 & 24,69 & 2,92 \\
\hline & Hayır & 222 & 24,56 & 2,93 \\
\hline & Toplam & 458 & 24,62 & 2,92 \\
\hline \multirow[t]{3}{*}{ Çatışmayı kolaylaştırma } & Evet & 236 & 26,47 & 3,39 \\
\hline & Hayır & 222 & 26,68 & 3,28 \\
\hline & Toplam & 458 & 26,57 & 3,34 \\
\hline \multirow[t]{3}{*}{ Çatışmayı uzlaştırma } & Evet & 236 & 25,64 & 3,03 \\
\hline & Hayır & 222 & 25,78 & 3,07 \\
\hline & Toplam & 458 & 25,71 & 3,05 \\
\hline \multirow[t]{3}{*}{ Çatışmaya karşı koyma } & Evet & 236 & 26,14 & 2,74 \\
\hline & Hayır & 222 & 25,98 & 2,65 \\
\hline & Toplam & 458 & 26,06 & 2,69 \\
\hline
\end{tabular}

Tablo 5'e bakıldığında üniversite öğrencilerinin daha önce romantik kadın/erkek arkadaşıyla bir ayrılık yaşayanların eşitlikçi cinsiyet rolü ortalamasının $(\bar{X}=13,85)$, bir ayrılık 
yaşamayanlara $(\bar{X}=14,04)$ göre daha düşük düzeyde olduğu görülmüştür. Üniversite öğrencilerinin daha önce romantik kadın/erkek arkadaşıyla bir ayrılık yaşayanların kadınsı cinsiyet rolü ortalamasının $(\bar{X}=24,33)$, bir ayrılık yaşamayanlara $(\bar{X}=25,95)$ göre daha düşük düzeyde olduğu görülmüştür. Üniversite öğrencilerinin daha önce romantik kadın/erkek arkadaşıyla bir ayrılık yaşayanların evlilikte cinsiyet rolü ortalamasının $(\bar{X}=14,26)$, bir ayrılık yaşamayanlara $(\bar{X}=13,74)$ göre daha yüksek düzeyde olduğu görülmüştür. Üniversite öğrencilerinin daha önce romantik kadın/erkek arkadaşıyla bir ayrılık yaşayanların geleneksel cinsiyet rolü ortalamasının ( $\bar{X}=23,51)$, bir ayrılık yaşamayanlara $(\bar{X}=23,47)$ göre daha yüksek düzeyde olduğu görülmüştür. Üniversite öğrencilerinin daha önce romantik kadın/erkek arkadaşıyla bir ayrılık yaşayanların erkeksi cinsiyet rolü ortalamasının $(\bar{X}=13,15)$, bir ayrılık yaşamayanlara $(\bar{X}=13,28)$ göre daha düşük düzeyde olduğu görülmüştür. Üniversite öğrencilerinin daha önce romantik kadın/erkek arkadaşıyla bir ayrılık yaşayanların toplumsal cinsiyet rolü ortalamasının ( $\bar{X}=89,13)$, bir ayrılık yaşamayanlara $(\bar{X}=90,5)$ göre daha düşük düzeyde olduğu görülmüştür. Üniversite öğrencilerinin daha önce romantik kadın/erkek arkadaşıyla bir ayrılık yaşayanların çatışmadan kaçınmacı stil ortalamasının $(\bar{X}=20,77)$, bir ayr1lık yaşamayanlara $(\bar{X}=20,94)$ göre daha düşük düzeyde olduğu görülmüştür. Üniversite öğrencilerinin daha önce romantik kadın/erkek arkadaşıyla bir ayrılık yaşayanların çatışmayı zorlayıcı stil ortalamasının ( $\bar{X}=24,69)$, bir ayrılık yaşamayanlara $(\bar{X}=24,56)$ göre daha yükssek düzeyde olduğu görülmüştür. Üniversite öğrencilerinin daha önce romantik kadın/erkek arkadaşıyla bir ayrılık yaşayanların çatışmayı uzlaştırmacı stil ortalamasının ( $\bar{X}=25,64)$, bir ayrılık yaşamayanlara ( $\bar{X}=25,78)$ göre daha düşük düzeyde olduğu görülmüştür. Üniversite öğrencilerinin daha önce romantik kadın/erkek arkadaşıyla bir ayrılık yaşayanların çatışmaya karşı koyucu ortalamasının ( $\bar{X}=26,14)$, bir ayrılık yaşamayanlara $(\bar{X}=25,98)$ göre daha yüksek düzeyde olduğu görülmüştür.

Üniversite öğrencilerinin daha önce romantik kadın/erkek arkadaşıyla bir ayrılık yaşamasına ilişkin Tek Yönlü ANOVA sonuçları Tablo 6'da verilmiştir.

Tablo 6

Üniversite Öğrencilerinin Daha Önce Romantik Kadın/Erkek Arkadaşıyla Bir Ayrılık Yaşamasına İlişkin Tek Yönlü ANOVA Sonuçları

\begin{tabular}{|c|c|c|c|c|c|c|}
\hline & & $\begin{array}{l}\text { Kareler } \\
\text { toplam1 }\end{array}$ & df & $\begin{array}{l}\text { Kareler } \\
\text { ortalamas1 }\end{array}$ & $\mathrm{F}$ & $\mathrm{P}$ \\
\hline \multirow{3}{*}{$\begin{array}{l}\text { Eşitlikçi cinsiyet } \\
\text { rolü }\end{array}$} & Gruplar arası & 4,09 & 1 & 4,09 & ,22 & ,635 \\
\hline & Gruplar içi & 8282,65 & 456 & 18,16 & & \\
\hline & Toplam & 8286,74 & 457 & & & \\
\hline \multirow[t]{3}{*}{ Kadın cinsiyet rolü } & Gruplar arası & 300,29 & 1 & 300,29 & 7,81 &, 005 \\
\hline & Gruplar içi & 17518,1 & 456 & 38,41 & & \\
\hline & Toplam & 17818,39 & 457 & & & \\
\hline \multirow{3}{*}{$\begin{array}{l}\text { Evlilikte cinsiyet } \\
\text { rolü }\end{array}$} & Gruplar arası & 31,37 & 1 & 31,37 & 1,71 & ,192 \\
\hline & Gruplar içi & 8362,54 & 456 & 18,33 & & \\
\hline & Toplam & 8393,92 & 457 & & & \\
\hline \multirow{3}{*}{$\begin{array}{l}\text { Geleneksel } \\
\text { cinsiyet rolü }\end{array}$} & Gruplar arası &, 17 & 1 & ,17 & ,00 & ,949 \\
\hline & Gruplar içi & 19860,32 & 456 & 43,55 & & \\
\hline & Toplam & 19860,49 & 457 & & & \\
\hline \multirow[t]{4}{*}{ Erkek cinsiyet rolü } & Gruplar arası & 1,97 & 1 & 1,97 &, 11 & ,735 \\
\hline & Gruplar içi & 7872,74 & 456 & 17,26 & & \\
\hline & Toplam & 7874,72 & 457 & & & \\
\hline & Gruplar arası & 217,11 & 1 & 217,11 & ,48 & ,487 \\
\hline
\end{tabular}




\begin{tabular}{|c|c|c|c|c|c|c|}
\hline $\begin{array}{l}\text { Toplumsal } \\
\text { cinsiyet rolü }\end{array}$ & Toplam & $\begin{array}{r}204732,4 \\
1 \\
204949,5 \\
2\end{array}$ & 456 & 448,97 & & \\
\hline \multirow{3}{*}{$\begin{array}{l}\text { Çatışmadan } \\
\text { kaçınma }\end{array}$} & Gruplar arası & 3,49 & 1 & 3,49 & ,28 &, 597 \\
\hline & Gruplar içi & 5680,99 & 456 & 12,45 & & \\
\hline & Toplam & 5684,48 & 457 & & & \\
\hline \multirow[t]{3}{*}{ Çatışmayı zorlama } & Gruplar arası & 1,86 & 1 & 1,86 & ,21 & ,641 \\
\hline & Gruplar içi & 3911,03 & 456 & 8,57 & & \\
\hline & Toplam & 3912,9 & 457 & & & \\
\hline \multirow{3}{*}{$\begin{array}{l}\text { Çatışmayı } \\
\text { kolaylaştırma }\end{array}$} & Gruplar arası & 5,05 & 1 & 5,05 & 45 &, 502 \\
\hline & Gruplar içi & 5094,77 & 456 & 11,17 & & \\
\hline & Toplam & 5099,82 & 457 & & & \\
\hline \multirow{3}{*}{$\begin{array}{l}\text { Çatışmayı } \\
\text { uzlaştırma }\end{array}$} & Gruplar aras1 & 2,24 & 1 & 2,24 & ,24 & ,624 \\
\hline & Gruplar içi & 4252,85 & 456 & 9,32 & & \\
\hline & Toplam & 4255,1 & 457 & & & \\
\hline \multirow{3}{*}{$\begin{array}{l}\text { Çatışmaya } \\
\text { koyma }\end{array}$} & Gruplar arası & 3 & 1 & 3 & ,41 &, 521 \\
\hline & Gruplar içi & 3323,03 & 456 & 7,28 & & \\
\hline & Toplam & 3326,03 & 457 & & & \\
\hline
\end{tabular}

Tablo 6 Üniversite öğrencilerinin daha önce romantik kadın/erkek arkadaşıyla bir ayrılık yaşamasına ilişkin Tek Yönlü ANOVA sonuçları incelendiğinde çatışma stillerinin gruplara göre anlamlı olarak farklılaşmadığı $(\mathrm{p}>0.05)$ görülmüştür. Cinsiyet rollerinin ise kadınsı cinsiyet rolü hariç diğer alt boyutlarının anlamlı olarak farklılaşmadığı görülmüştür Kadınsı cinsiyet rolünün ise anlamlı olarak farklılaştığı görülmüştür $[\mathrm{F}(1-456)=7,81, \mathrm{p}<.05]$. Farkın hangi gruplar arasında olduğuna bakıldığında üniversite öğrencilerinin daha önce romantik kadın/erkek arkadaşıyla bir ayrılık yaşayanların kadınsı rolü ortalamasının $(\bar{X}=24,33)$, bir ayrılık yaşamayanlara $(\bar{X}=25,95)$ göre anlamlı olarak daha düşük düzeyde olduğu görülmüştür.

\section{Tartışma ve Sonuç}

Tartışma ve sonuç bölümünde bulgular, ilgili literatür çerçevesinde tartışılarak yorumlanmıştır. Araştırmanın sonucuna göre eşitlikçi cinsiyet rolünün çatışmadan kaçınmacı stil ile zayıf düzeyde pozitif yönde diğer çatışma stilleri ile negatif yönde ilişkili olduğu, kadınsı cinsiyet rolünün çatışmaya karşı koyucu stili ile negatif yönde diğer çatışma stilleri ile pozitif yönde ilişkili olduğu ortaya çıkmıştır. Evlilikte cinsiyet rolünün çatışmayı kolaylaştırıcı ve çatışmaya karşı koyucu stilleri ile negatif yönde diğer stilleri ile pozitif yönde ilişskili olduğu ortaya çıkmıştır. Geleneksel cinsiyet rolleri ile erkeksi cinsiyet rollerinin çatışmaya karşı koyucu rol ile negatif yönde diğer stiller ile pozitif yönde ilişkili olduğu ortaya çıkmıştır. Bu sonuçlara göre toplumsal cinsiyet rolleri ile çatışma çözme stilleri arasında ilişki olduğu söylenebilir. Eşitlikçi toplumsal cinsiyet rolleri artıkça öğrencilerin çatışmadan kaçındığ 1 görülmektedir. $\mathrm{Bu}$ sonucun nedeni ise çatışmadan kaçınan öğrencilerin içinde bulundukları toplumsal yapı ile açıklanabilir. Çünkü bir taraftan toplum tarafından kadın ve erkek rolleri ile ilgili eşitlikçi bir tutum sergilenmesi önerilirken, diğer yandan herhangi bir problem durumunda da sessiz kalınmak ve kaçınmak da öneriliyor olabilir. Benzer olarak eşitlikçi cinsiyet rolü ile çatışmayı kaşı koyma arasında negatif yönde bir sonuç çıkmasının beklenir olduğu düşünülmektedir. Eşitilikçi bir tutum sergileyenlerin çatışmadan kaçınması, aynı zamanda çatışmaya karşı koyamayabilecekleri düşünülmektedir. Yapılan benzer çalışmalara bakıldığında da geleneksel cinsiyet rolleri ile kişiler arası ilişkilerde çatışma yönetimi, şiddet, ailenin geliri, eğitim düzeyi ile ilişkili olduğu ortaya çıkmıştır (KodanÇetinkaya, 2013; Schwarzwald, Koslowsky, Izhak-Nir, 2008). Yapılan bir diğer benzer çalışmada bu araştırmanın bulgularını destekler niteliktedir. Yetişkinlerle yaptığı çalışmada Yücel (2013) 
çatışma stilleri ile cinsiyet rolleri arasında anlamlı ilişkiler saptamıştır. Araştırmanın bir diğer bulgusuna göre, eşitlikçi cinsiyet rollerinin, kadınsı cinsiyet rollerinin, erkeksi cinsiyet rollerinin, evlilikte cinsiyet rollerinin, geleneksel cinsiyet ve toplumsal cinsiyet rollerinin erkeklerin ortalamasının kadınlara oranla anlamlı olarak daha yüksek olduğu ortaya çıkmıştır. Buna göre üniversite öğrencilerinin toplumsal cinsiyet rollerinin bütün alt boyutlarında erkeklerin ortalamasının kadınlara oranla anlamlı olarak daha yüksek olduğu söylenebilir. Ayrıca cinsiyete göre çatışma stillerinin anlamlı olarak farklılaşmadığı ortaya çıkmıştır. Benzer bir diğer çalışmada da Tekkanat (2009) çatışma yönetimi stratejilerinin cinsiyet değişkenine göre anlamlı farklılaşmadığı sonucunu bulmuştur. Buna göre cinsiyete göre çatışma stillerinin anlamlı olarak farklılaşmadığı söylenebilir. Toplumsal cinsiyet rollerine ilişkin sonuçlara bakıldığında ise, erkeklerin kadınlara göre daha hem geleneksel cinsiyet hem de eşitlikçi cinsiyet rollerine ilişkin ortalamalarının anlamlı olarak daha yüksek olduğu ortaya çıkmıştır. Bu sonuç erkeklerin kendilerini daha eşitlikçi algılamalarının gerçekte öyle olduğu sonucunu çıkarmayabilir. Çünkü sonuçlara bakıldığında aynı zamanda erkeklerin kadınlara göre daha geleneksel cinsiyet rollerine sahip olduklarını göstermektedir. Bu sonuç ile paralel olarak Öngen ve Aytaç (2013) üniversite öğrencileri ile yaptıkları çalışmalarında erkeklerin kadınlara göre daha geleneksel cinsiyet rollerinin olduğunu ortaya koymuşlardır. Türk toplumunda cinsiyet rolü yöneliminin geleneksel cinsiyet rolü yönelimine daha yakın olduğuna ilişkin araştırma bulguları bulunmaktadır (Girginer, 1994; Kavuncu, 1987). Aynı zamanda Bal (2007) kadınlarda androjen tip özelliklerinin yüksek olduğunu ortaya koymuştur. Androjen cinsiyet rolü bireylerin hem kadınsı hem de erkeksi özellikleri bir arada ve farklı derecelerde sergilediği cinsiyet rolü olarak tanımlanmıştır (Mayer ve Sutton, 1996). Benzer bir başka çalışmada Çavdar (2013) kadınların erkeklere oranla daha az geleneksel toplumsal cinsiyet rolüne sahip olduğu görülmüştür. Dolayısıyla kadın ve erkek üniversite öğrencilerinin cinsiyet rollerine ilişkin tutumlarının farklı olduğu söylenebilir. Bunun nedeninin ise cinsiyet rollerine ilişkin anne-baba tutumları ve kültürel öğrenmelerin etkili olabileceği düşünülmektedir.

Araştırmanın bir diğer bulgusuna göre üniversite öğrencilerinin yakın bir ilişkisi (romantik kadın/erkek) olmasına göre çatı̧̧ma stillerinin, evlilikte cinsiyet, geleneksel cinsiyet ve erkeksi cinsiyet rollerinin anlamlı olarak farklılaşmadığı, buna karşılık eşitlikçi cinsiyet rolünün, kadınsı cinsiyet ve toplumsal cinsiyet rolünün anlamlı olarak farklılaştığı görülmüsştür. Buna göre, üniversite öğrencilerinin yakın bir ilişkisi (romantik kadın/erkek) olanların olmayanlara göre eşitlikçi cinsiyet rolünün, kadınsı cinsiyet ve toplumsal cinsiyet rolünün anlamlı olarak daha düşük düzeyde olduğu görülmüştür. Bu sonuca göre üniversite öğrencilerinden yakın ilişkisi olanların eşitlikçi bir tutum içinde olmadıkları, daha geleneksel oldukları ve kadınlara özgü cinsiyet rolleri özelliklerini göstermedikleri anlaşılmaktadır. Bunun aksine yakın bir ilişkisi olmayanların daha eşitlikçi ve kadınlara özgü cinsiyet tutumlarını benimsedikleri söylenebilir. Papp, Goeke-Morey ve Cummings (2007) ilişkileri her bir çiftin psikolojik stres ve çatışma stratejilerine göre incelenmesi gerektiğini belirtmektedirler. Bem (1974) cinsiyet rolü yöneliminin daha fazla kadınsı ve daha az erkeksi özelliklere sahip bireylerin kadınsı (feminine) cinsiyet rollerine sahip olduklarını, daha fazla erkeksi ve daha az kadınsı özelliklere sahip bireylerin de erkeksi (masculine) cinsiyet rolleri yönelimine sahip olduklarını belirtmektedir. Ayrıca bireyler hem daha fazla erkeksi ve hem de daha fazla kadınsı özelliklere aynı zamanda sahipse androjen (androgyn), her iki tür özelliklerden de daha az taşıyanlara ise ayrışmamış (undifferentiated) olarak tanımlamaktadır. Yapılan benzer bir diğer çalışmada da cinsiyet rolleri ile yakın ilişkilerde sağlanan doyum arasında bir ilişki bulunmuştur (Donaghue ve Fallon, 2003).

Üniversite öğrencilerinin daha önce romantik kadın/erkek arkadaşıyla bir ayrılık yaşamasına ilişkin çatışma stillerinin anlamlı olarak farklılaşmadığ 1 görülmüştür. Cinsiyet rollerinin ise kadınsı cinsiyet rolü hariç diğer alt boyutlarının anlamlı olarak farklılaşmadığ görülmüştür. Üniversite öğrencilerinin daha önce romantik kadın/erkek arkadaşıyla bir ayrılık yaşayanların kadınsı cinsiyet rolü ortalamasının bir ayrılık yaşamayanlara göre anlamlı olarak daha düşük düzeyde olduğu görülmüsstür. Bu sonuca göre daha önce romantik kadın/erkek arkadaşıyla bir ayrılık yaşayanların kadınsı cinsiyet rollerinin daha düşük düzeyde olduğu söylenebilir. Bu sonuç ayrılma ile kadınsı özelliklerin ilişkilendirilmesi ile ilgili olabilir. Yapılan 
benzer bir diğer çalışmada Bahadır (2006) yaşanmış ilişki sayısı ile güven duygusu ve çatışma arasında negatif yönde korelasyon ortaya çıkarmıştır. Bu bulgu ayrılıkla sonuçlanan daha fazla sayıda ilişki yaşamış olan bireylerin daha sonraki ilişkilerinde kendilerini güvende hissetmedikleri ve görüş ayrılıklarını ifade etmede zorlandıkları şeklinde yorumlanmıştır. Tezer ve Demir (2001) üniversite öğrencileri ile yaptıkları çalışmalarında erkeklerin erkek arkadaşlarına yönelik yarışmacı, kadın akranlarına karşı ise kaçınma davranışı gösterdiklerini ortaya çıkarmışlardır. Can (2006) duygusal bir ilişkisi bulunan genç yetişkinlerin ilişkiden çok doyum alan gruptaki gençler ilişkiden az doyum alan gruptakilere göre daha sıklıkla işbirliğine girmektedirler. Uyma alt boyutunun, ilişki doyumu ve ilişki süresi analizlerinde cinsiyetin temel etkisi manidar çıkmıştır: Erkeklerin çatışmalarda, sevgililerine daha fazla uydukları sonucuna ulaşılmıştır. İlişkiden doyum alan gruptaki gençlerin uzlaşma puanları, ilişkilerinden az doyum alan gruptaki gençlere göre anlamlı ölçüde yüksektir.

\section{Öneriler}

$\mathrm{Bu}$ araştırmanın sonuçlarına göre şu önerilerde bulunulabilir. 1. Cinsiyet rolleri ile ilişkili olabilecek çatışma stillerinin psikolojik danışma sürecinde ele alınması gerektiği önerilebilir. 2. Toplumsal cinsiyet rollerinin gelişimi ve kişilerarası ilişkilerde çatışma stilleri ile ilgili programlar geliştirilerek grupla psikolojik danışma oturumları uygulanabilir. 3. Yakın ilişkileri olan üniversite öğrencilerine yönelik kişilerarası ilişkilerindeki çatışmaları azaltmaya yönelik Üniversite Psikolojik Danışma Merkezlerinde, Halk Eğitim Merkezlerinde psikolojik danışmanlar tarafından cinsiyet rollerine yönelik grupla psikolojik danışma oturumları düzenlenebilir.

\section{Kaynaklar}

Altuntaş, O. ve Altınova, H. H. (2015). Determining the relationship between gender perception and socioeconomic variables. Turkish Studies, 10(6), 83-100.

Aydın, A. S. (2003). Ergenlerde stresle başa çıkma tarzları ile cinsiyet ve cinsiyet rolleri arasındaki ilişki (Yayımlanmamış yüksek lisans tezi). Marmara Üniversitesi, İstanbul.

Bal, H. (2007). Bağlanma stilleri, cinsiyet rolleri ve evlilik uyumu arasındaki ilişkinin incelenmesi (Yayımlanmamış yüksek lisans tezi). Mersin Üniversitesi Eğitim Bilimleri Enstitüsü, Mersin.

Bahadır, Ş. (2006). Romantik ilişkilerde bağlanma stilleri, çatışma çözme stratejileri ve olumsuz duygu durumunu düzenleme arısındaki ilişki (Yayımlanmamış doktora tezi). Ankara Üniversitesi, Ankara.

Bem, S. (1974). The measurement of psychological androgyny: a reply to the pedhazur tetanbaum and locksley-colten critiques. Journal of Consulting and Clinical Psychology, 42(2), 155162.

Bem, S. L. (1993). The lenses of gender: trans-forming the debate on sexual inequality. New Haven: Yale University Press.

Bhasin, K. (2003). Toplumsal cinsiyet (K. Ay, Çev.) İstanbul: Kadınlarla Dayanışma Vakfı Yayınları.

Can, S. (2006). Genç yetişkinlik dönemindeki bireylerin karşı cinsle duygusal iliş̧kilerindeki çatışma çözme biçimlerinin incelenmesi (Yayımlanmamış yüksek lisans tezi). Ankara Üniversitesi, Ankara.

Choi, N. (2004). Sex-Role group differences in spesific, academic and general self-efficacy. The Journal of Psychology. 138(2), 149-159.

Çavdar, D. (2013). Üniversite öğrencilerinin toplumsal cinsiyet rollerine ilişkin tutumları ve romantik ilişkilerde akilci olmayan inançlar (Yayımlanmamış yüksek lisans tezi). Ankara Üniversitesi, Ankara.

Dusek, J. B. (1987). Adolescent development and behavior. Prentice - Hall, Inc. A Division of Simon and Schuster, New Jersey.

Deutsch, M. (1994). Constructive conflict resolution: Principles, training, and research. Journal of Social Issues, 50, 13-22. 
Dökmen, Z. (2004). Toplumsal cinsiyet. İstanbul: Sistem Yayıncılık.

Donaghue, N. ve Fallon, B. J. (2003). Gender-role self-stereotyping and the relationship between equity and satisfaction in close relationships. Sex Roles, 48, 217-230.

Helgeson, V. (2012). The psychology of gender-fourth edition. Usa: Pearson.

Hendrick, S. (2009). Yakın ilişkiler psikolojisi, (A. Dönmez ve A. Büyükşahin, Çev.). Ankara: Nobel Yayın Dağıtım.

Gander, M. J. ve Gardiner, H. W. (1995). Çocuk ve ergen gelişimi, B. Onur (Yay. haz.). Ankara: İmge Kitapevi.

Giddens, A. (1996). Introduction to sociology. New York: W.W. Norton \&Company, Inc.

Girginer, H. U. (1994). Türk toplumunda cinsiyet rolleri algısı (Yayımlanmamış yüksek lisans tezi). Ege Üniversitesi, İzmir.

Johnson, D. W. ve Johnson, F. P. (2003). Joining together. New York: Pearson Education Inc.

Johnson, D. W. ve Johnson, F. P. (2008). Joining together: Group theory and group skills. Boston: Allyn \& Bacon.

Kahraman, B. A., Ozansoy-Tunçdemir, N. ve Özcan, A. (2015). Toplumsal cinsiyet bağlamında hemşirelik bölümünde öğrenim gören erkek öğrencilerin mesleğe yönelik algıları, Sosyoloji Araştırmaları Dergisi, 18(2),108-144.

Karadağ, E. ve Tosun, Ü. (2014). Çatışma eylem stilleri ölçeği [ÇESÖ]: Türkçe’ye uyarlanması dil geçerliği ve ön psikometrik incelemesi, Psikoloji Çalışmaları Dergisi, 34(1), 45-69.

Karip, E. (2010). Çatışma yönetimi. Ankara: Pegem A Yayınları.

Kavuncu, A. N. (1987). Bem Cinsiyet Rolü Envanteri'ni Türk toplumuna uyarlama çalışmaları (Yayımlanmamış yüksek lisans tezi). Hacettepe Üniversitesi, Ankara.

Kodan-Çetinkaya, S. (2013). Üniversite öğrencilerinin şiddet eğilimlerinin ve toplumsal cinsiyet rollerine ilişkin tutumlarının incelenmesi. Nesne Dergisi, 1(2), 21-43.

Mahalik, J. R. (2000). Gender role conflict in men as a predictor of self-ratings of behavior on the interpersonal circle. Journal of Social and Clinical Psychology, 19(2), 276-292.

Mayer, B. (2000). The dynamics of conflict resolution. New York: John Wiley and Sons.

Mayer, F. S. ve Sutton, K. (1996). Personality: An integrative approach. New Joursey, Prentice Hall.

Moscovitch, D. A., Hofmann, S. G. ve Litz, B. T., (2005). The impact of social anxiety: A genderspecific interaction. Personality and Individual Differences, 39, 659-672.

Öngen, B. ve Aytaç, S. (2013). Üniversite öğrencilerinin toplumsal cinsiyet rollerine ilişkin tutumları ve yaşam değerleri ilişkisi. Sosyoloji Konferansları Dergisi, 48, 1-18.

Papp, L. M., Goeke-Morey, M. C. ve Cummings, E. M. (2007). Linkages between spouses' psychological distress and marital conflict in home. Journal of Family Psychology, 21, 533-537.

Rahim M. A. (2001). Managing conflict in organizations. 3rd Edition, Quorum Books, Westport, USA.

Rose, A. J. ve Asher, S. R. (1999). Children's goals and strategies in response to conflict within a friendship. Developmental Psychology, 35, 69-79.

Schwarzwald, J., Koslowsky, M. ve Izhak-Nir, E. (2008). Gender role 1deology as a moderator of the relationship between social power tactics and marital satisfaction. Sex Roles, 59, 657669.

Sevim, S. A. (2005). Üniversite öğrencilerinin çatışmalara yaklaşım biçimleri. Eğitim Araştırmaları Dergisi, 5, 223-233.

Tezer, E. (2001). Conflict behaviors and their relationship to popularity. Adolescence, 36, 6- 24.

Tüfekçi, S. (2008). Romantik ilişsilerde genç yetişkinlerin aşka ilişkin tutumları ve kişilik özellikleri: Transaksiyonel analiz ego durumları açısından bir değerlendirme (Yayımlanmamış yüksek lisans tezi). Marmara Üniversitesi, İstanbul.

Tekkanat, D. (2009). İlköğretim okulu yöneticilerinin çatışma yönetimi tarzlarına ilişkin ögretmen algıları (Yayımlanmamış yüksek lisans tezi). Sakarya Üniversitesi, Sakarya.

Tezer, E. ve Demir, A. (2001) Conflict behaviors toward same-sex peers among male and female late adolescents. Adolescense, 36, 525-534. 
Uğurlu, O. (2003). The relationships between sexism, conflict management strategies and marital adjustment in married couples (Yayımlanmamış yüksek lisans tezi). Ankara Üniversitesi, Ankara.

Vefikuluçay, D., Zeyneloğlu, S., Eroğlu, K. ve Taşkın, L. (2007). Kafkas Üniversitesi son sınıf öğrencilerinin toplumsal cinsiyet rollerine ilişkin bakış açıları. Hacettepe Üniversitesi Hemşirelik Yüksekokulu Dergisi, 26-38.

Yücel, F. G. (2013). Examining the relationship between projective identification, gender roles, conflict resolution styles and marital satisfaction (Yayımlanmamış yüksek lisans tezi). İstanbul Bilgi Üniversitesi, İstanbul.

Zeyneloğlu, S. ve Terzioğlu, F. (2011). Toplumsal cinsiyet rolleri tutum ölçeğinin geliştirilmesi ve psikometrik özellikleri. Hacettepe Üniversitesi Eğitim Fakültesi Dergisi, 40, 409420.

\section{Extended Abstract \\ Introduction}

Gender role refers to the cultural expectations from woman and man in a society (Helheson, 2012). Gender involves the social and cultural definition of female and male, social distinction between female and male, and the social roles. Gender roles were stated to be tools for understanding the social truth of female and male (Bhasin, 2003). Bem (1993) emphasized that personal characteristics of female and male were defined in every culture and society. The researcher stated that woman and man, hence, differed in social status and the tasks to be accomplished. Thus, starting from childhood, the individual learns the behaviors, tasks, and responsibilities of female and male. Cognitive schemes of feminine and masculine roles, based on the social definition of female and male, were stated to be developed. A review of studies in relevant literature indicated that gender roles were associated with many variables. Gender roles were found to be associated with individuals' self-esteem (Choi, 2004), styles of coping with stress (Aydın, 2003), and social anxiety (Moscovitch, Hofmann \& Litz, 2004). In addition, traditional gender roles and interpersonal relationships were found to be associated with conflict management, violence, family income, and education level (Kodan-Çetinkaya, 2013; Schwarzwald, Koslowsky \& Izhak-Nir, 2008). Positive emotions and thoughts as well as violence were stated to be experienced in conflicts. Thus, it was stated that conflicts could have beneficial consequences for the individual and his/her interpersonal relationships (Johnson \& Johnson, 2003). Conflict is defined as a normal truth of human life (Karip, 2010; Rahim, 2001). Conflict resolution, on the other hand, is an important skill used to sustain the individual's relationships. Karip (2010) defined conflict resolution as the state of eventuating with reconciliation or agreement between the parties in the conflict. Johnson and Johnson (2008) reported that five basic dimensions of coping with conflict were available: avoiding conflict, pushing the conflict, facilitating the conflict, resolving the conflict, and resisting the conflict. Towards the end of adolescence, it is more possible to resolve conflicts through constructive strategies during their cognitive development (Deutsch, 1994; Mayer, 2000). Hence, conflict resolution strategies in university students become important in terms of interpersonal and intimate relationships. Particularly, studying the relationship between university students' attitudes towards gender roles and their conflict resolution styles is thought to be important. Research on these variables is considered a potential contribution in psychological counselling services offered to university students. Thus, the current study aims to study the relationship between gender roles and conflict resolution in university students.

\section{Methods \\ Participants}

Research participants consisted of totally 458 individuals $\left(\bar{X}_{\text {age }}=22.39, S D=1.76\right.$, range $=19-37$ ) including 209 (45.6\%) males and 249 (54.4\%) females attending Adiyaman University in 20152016 academic years in Turkey. 25 (5.5\%) of the participants were sophomores; 291 (63.5\%) were juniors; and $142(31 \%)$ were seniors. $238(52 \%)$ participants attended the faculty of 
education; $173(37.8 \%)$ attended the faculty of business administration; $30(6.6 \%)$ studied in the faculty of arts and sciences; and 17 (3.7\%) attended the faculty of engineering.

\section{Results}

The means of egalitarian gender roles, feminine gender roles and masculine gender roles, gender roles in marriage, traditional gender roles, and social gender roles in males were found to be significantly higher than those in females. In addition, conflict styles were found not to differ on gender. In a similar study, Tekkanat (2009) found that conflict management strategies did not significantly differ on the variable of gender. Thus, conflict styles can be said not to differ on gender. Another finding in the current study indicated that conflict styles, gender in marriage, traditional gender, and masculine gender did not differ, but egalitarian gender role, feminine gender role, and social gender roles differed on whether university students had an intimate relationship (female/male romantic relationship). Hence, egalitarian gender role, feminine gender role, and social gender roles in university students with intimate relationships (female/male romantic relationships) were found to be on significantly lower levels than those of university students without intimate relationships. Such result indicated that university students having intimate relationships did not have egalitarian attitudes; were more traditionally oriented; and did not exhibit the characteristics of feminine gender role. Conversely, those students without intimate relationships could be considered to be more egalitarian and to embrace feminine gender roles. Papp, Goeke-Morey and Cummings (2007) stated that relationships had to be studied based on each pair's psychological stress and conflict strategies. University students' conflict styles were found not to differ on whether they had a breakup with their girl/boyfriends. Also, except feminine gender role, all sub-dimensions of gender roles were found not to differ. The feminine gender role of the university students experiencing a breakup with a romantic girl/boyfriend were found to be on significantly lower levels than that of those students experiencing no breakup with a romantic girl/boyfriend. Hence, feminine gender roles of those students previously experiencing a breakup with romantic girl/boyfriend could be considered to be on lower levels. This result may be associated with linking the breakup with feminine characteristics. In another similar research, Bahadır (2006) found a negative correlation between the number of experienced relationships and self-esteem and conflict. Such result was interpreted to indicate that individuals experiencing more relationships ending with breakups did not feel safe in later relationships and had difficulties expressing their disagreements. Demir (2001) found in his/her study with university students that males exhibited competitive behaviors towards their male friends and avoiding behaviors towards their female peers.

\section{Suggestions}

Following suggestions may be put forward based on the results of the current study:

1. As a relationship between gender roles and conflict styles was available, conflict styles that could be associated with gender roles can be suggested to be considered in the psychological counselling process,

2. Both egalitarian and traditional gender roles in male university students, compared to female students, were found to be on higher levels. As such result could not indicate that males were both egalitarian and traditional, this is indeed an indicator of a contradiction. Namely, males' selfperception of being both egalitarian and traditional does not mean that they actually are. Hence, group psychological counselling sessions about the awareness of gender roles can be organized,

3. Current research results indicated that egalitarian gender role, feminine gender role, and social gender roles of university students having intimate relationships (romantic girl/boyfriend) were on significantly lower levels than those of students having no intimate relationships. Based on this result, university students with intimate relationships can be regarded as non-egalitarian and more traditional. Thus, group psychological counselling sessions on gender roles, in order for university students with intimate relationships to reduce conflicts in relationships, can be organized within University Psychological Counselling Centers and Public Education Centers by psychological counsellors. 